\title{
Teologia e literatura como teopatodiceia: em busca de um pensamento poético teológico
}

\author{
Orientadora: Maria Clara Lucchetti Bingemer \\ Doutorando: Alex Villas Boas Oliveira Mariano \\ Área de Concentração: Teologia Sistemático-Pastoral \\ Linha de Pesquisa: Religião e Modernidade
}

O presente trabalho tem como objeto material da pesquisa a busca de sentido da vida ou patodiceia inspirada na logoteoria de Viktor Emmil Frankl (1905-1997) e o que a teologia tem a contribuir com a questão, verificando a sua capacidade de recepção sensível à problemática a partir da construção de uma teopatodiceia, no qual a teologia é vista como pergunta pelo sentido [logos] de Deus [Theós] na busca de sentido humana, tendo por base a lógica de conhecimento existencial extraída da teologia dos Exercícios de Espirituais de Santo Inácio de Loyola de Karl Rahner (1904-1984) como forma de explicitar a dimensão da existência cristã presente em sua antropologia teológica. Também é parte da proposta deste trabalho encontrar critérios para formular uma razão literária como elemento formal adequado a proposta da patodiceia, e consequentemente, da teopatodiceia, resultando assim naquilo que chamamos de pensamento poético teológico, como forma de desvelamento de sentido, melhor explicitando assim o elemento existencial das fórmulas teológicas, por um empréstimo de pensamento da Literatura.

Palavras-chave: Teologia e literatura, busca de sentido, teopatodiceia. 